\title{
Adaptive Cycle of The Wotsogo Village Community in Facing Covid-19 Pandemic in 2020
}

\author{
Diah Ainurrohmah, Rita Noviani, Yasin Yusup \\ Universitas Sebelas Maret \\ diahainur@student.uns.ac.id
}

\section{Article History}

accepted 31/08/2020

approved 22/09/2020

published 28/10/2020

\begin{abstract}
COVID-19 is non-natural disaster that influenced in various sector of life, not only health, but also social-economic conditions, including Wotsogo Village. Therefore, it is important to conduct research related to adaptive cycle of Wotsogo Village community in facing of COVID-19. This adaptive cycle can reflect the level of community resilience which influenced by various factors. This research used descriptive qualitative method with Miles and Huberman's interactive model and scoring technique analysis. The results of the analysis show that adaptive cycle of Wotsogo Village community in facing of COVID-19 was marked by three moments distribution, were the first distribution moment of COVID-19 in Indonesia, the second moment is implementation of COVID-19 policies, and last the towards New Normal moment. The scoring results show that the level of resilience of the Wotsogo Village community was classified as moderate that spread in three $R W$ areas and high that spread in nine RW areas.
\end{abstract}

Keywords: COVID-19, Adaptvie Cycle, Distribution Moment, Resilience

\begin{abstract}
Abstrak
COVID-19 merupakan bencana non-alam yang berdampak dalam berbagai bidang kehidupan, bukan hanya kesehatan, tapi kondisi sosial-ekonomi pun turut terpengaruh, tak terkecuali di Desa Wotsogo. Oleh sebab itu, penting untuk dilakukan penelitian terkait siklus adaptif masyarakat Desa Wotsogo dalam menghadapi Pandemi COVID-19. Siklus adaptif tersebut dapat mencerminkan tingkat resiliensi masyarakat yang dipengaruhi oleh beragam faktor. Metode yang digunakan dalam penelitian ini adalah deskriptif kualitatif dengan teknik analisis model interaktif Miles dan Huberman untuk mengetahui momen persebaran COVID-19 dan skoring untuk mengetahui tingkat resilinensi masyarakat. Hasil analisis menunjukkan bahwa siklus adaptif masyarakat Desa Wotsogo dalam menghadapi COVID-19 ditandai oleh serangkaian momen persebaran COVID-19 yang bisa dibagi menjadi tiga, yaitu Momen awal perkembangan COVID-19 di Indonesia, Momen pemberlakuan kebijakan yang berkaitan dengan COVID-19, dan Momen menuju New Normal. Hasil skoring menunjukkan bahwa tingkat resiliensi masyarakat Desa Wotsogo tergolong sedang yang tersebar di 3 wilayah RW dan tinggi yang tersebar di 9 wilayah RW.
\end{abstract}

Kata kunci: COVID-19, Siklus Adaptif, Momen Persebaran, Resiliensi

Social, Humanities, and Education Studies (SHEs): Conference Series https://jurnal.uns.ac.id/shes

p-ISSN 2620-9284 e-ISSN 2620-9292 


\section{PENDAHULUAN}

Coronavirus Disease-2019 (COVID-19) adalah penyakit menular yang disebabkan oleh Severe Acute Respiratory Syndrome Coronavirus 2 (SARS-COV2) yang termasuk dalam keluarga besar coronavirus yang ditemukan pada manusia sejak kejadian luar biasa muncul di Wuhan Cina, pada Desember 2019. Penyebab penyakit yang satu ini sama dengan penyebab SARS pada tahun 2003, hanya berbeda jenis virusnya, karena COVID-19 memiliki persebaran yang lebih luas dan cepat ke beberapa negara dibanding SARS (WHO, 2020).

Semua orang dapat terserang COVID-19, tapi orang-orang yang berusia lanjut, dan mereka yang memiliki masalah medis mendasar seperti penyakit kardiovaskular, diabetes, penyakit pernapasan kronis, dan kanker lebih rentan untuk terpapar penyakit serius. Virus COVID-19 menyebar terutama melalui tetesan air liur atau keluar dari hidung ketika orang yang terinfeksi batuk atau bersin (WHO, 2020).

Juru bicara WHO, Fadela Chaib (2020) dalam Iswara (2020) menegaskan bahwa semua bukti menunjukkan bahwa COVID-19 berasal dari hewan dan tidak dimanipulasi atau diproduksi di laboratorium, meskipun belum diketahui secara pasti bagaimana virus ini bisa melompat dari hewan ke manusia, tetapi "tentu saja" ada inang hewan perantara, yang diketahui bahwa inangnya adalah kelelawar.

Seiring perkembangannya, persebaran COVID-19 bukan hanya di Kota Wuhan, Cina saja, tapi kini telah tersebar pula di Indonesia. Persebaran COVID-19 di Indonesia terjadi melalui serangkaian momen yang bersifat dinamis, mulai dari masyarakat yang masih mengabaikan keberadaan virus tersebut karena Indonesia 0 kasus dan masyarakat merasa "kebal" terhadap COVID-19. Hingga secara resmi ada dua WNI yang dinyatakan positif terserang COVID-19, yaitu perempuan berusia 31 tahun dan ibu berusia 64 tahun, yang diumumkan oleh Presiden Joko Widodo pada bulam Maret 2020 lalu melalui media massa, pada tanggal 2 Maret 2020.

Seiring berjalannya waktu, jumlah orang yang terinfeksi virus ini pun semakin bertambah karena tingginya kecepatan persebaran virus corona, baik di Indonesia maupun di luar negeri. Melihat kecepatan persebaran COVID-19 tersebut, pada tanggal 11 Maret 2020, WHO menyatakan bahwa COVID-19 sebagai Global Pandemic.

Di Indonesia sendiri, jumlah penderita COVID-19 pun semakin bertambah. Hingga akhirnya pada tanggal 31 Maret 2020, Pemerintah Indonesia mengeluarkan PP Nomor 21 Tahun 2020 tentang Pembatasan Sosial Berskala Besar (PSBB), dan berdasarkan Keputusan Presiden Nomor 12 Tahun 2020 tentang Bencana Non-Alam, COVID-19 dinyatakan sebagai Nasional Disaster di Indonesia. Sebagaimana tindakan yang dilakukan oleh pemerintah di berbagai negara terdampak, Pemerintah Indonesia pun telah mengambil beberapa tindakan untuk mengurangi persebaran COVID-19 melalui physical distancing, anjuran memakai masker dan rajin mencuci tangan, beribadah dari rumah, bekerja dari rumah (Work From Home), kegiatan belajarmengajar dari berbagai tingkatan dilakukan dari rumah, pembatasan jumlah moda transportasi yang dapat beroperasi, pembatasan perjalanan ke luar negeri, hingga kebijakan lockdown.

Terdapat beragam prediksi terkait kapan masa puncak dan pandemi COVID-19 akan berakhir di Indonesia. Salah satunya yaitu prediksi dari Singapore University of Technology and Design. Berdasarkan penelitian yang dilakukan oleh Direktur Data Driven Innovation Lab yang juga dosen SUTD Prof Jianxi Luo bersama timnya yang menggunakan model SIR (susceptible-recover-recovered), diperkirakan 100\% akan berakhir pada 7 September 2020 (Nasution, 2020). Perkembangan kasus terbaru di Indonesia, berdasarkan laporan harian distribusi kasus COVID-19 per 23 Agustus 2020, dua provinsi dengan jumlah kasus terbanyak adalah DKI Jakarta (615 kasus) dan Jawa Timur (279 kasus) (Syambudi, 2020). 
Sebagai bencana nasional, pandemik COVID-19 telah berdampak pada seluruh wilayah yang ada di Indonesia, baik secara langsung, yaitu berkaitan dengan kondisi kesehatan masyarakat, maupun dampak tidak langsung, yaitu dampak terhadap kondisi masyarakat dalam berbagai bidang, termasuk kondisi fisik, sosial, ekonomi di suatu wilayah. Bahkan hal itu juga dirasakan hingga ke wilayah administrasi terkecil, yaitu desa. Tak terkecuali Desa Wotsogo, yaitu salah satu desa yang berada di Kecamatan Jatirogo, Tuban, Jawa Timur. Desa Wotsogo pun turut merasakan dampak tak langsung yang ditimbulkan oleh COVID-19, karena harus menyesuaikan segala aktivitasnya dalam berbagai bidang sesuai dengan arahan dan protokol kesehatan yang telah ditetapkan oleh pemerintah pusat.

Berkaca dari momen-momen penting terkait kasus perkembangan COVID-19 dalam skala nasional, Desa Wotsogo pun turut merasakan momen tersebut tapi dengan kondisi yang berbeda, karena perkembangan kasus COVID-19 di tiap-tiap wilayah pun berbeda. Hal itu tentunya dipengaruhi oleh beragam faktor, terutama adalah faktor masyarakat yang ada di wilayah yang bersangkutan. Momen-momen itulah yang nantinya dapat menggambarkan siklus adaptif masyarakat terbagi ke dalam beberapa tahapan, yaitu tahap pertumbuhan, tahap konservasi, tahap pengaturan ulang, dan tahap pembaruan, sebagaimana proses dalam Teori Panarchy (Holling dan Gunderson, 2002), yang mencerminkan tingkat resiliensi masyarakat (Holling, 1973), yang dapat dipengaruhi oleh beragam faktor yang menjadi variabel untuk menyusun indeks resiliensi (Cutter et al, 2010).

Secara sederhana, resiliensi bisa diartikan sebagai kemampuan untuk mempertahankan stabilitas psikologis dalam menghadapi stress Keye \& Pidgeon (2013). Sejalan dengan pendapat tersebut, Rojas, F (2015) juga menyatakan bahwa resiliensi merupakan kemampuan menghadapi tantangan. Resiliensi akan tampak ketika seseorang menghadapi pengalaman yang sulit dan tahu bagaimana menghadapi atau beradaptasi dengannya (Utami, 2017).

Situasi pandemi tentunya akan berpotensi menimbulkan tekanan terhadap sumberdaya dan mengancam keberlanjutan ekologis maupun sosial dan ekonomi tinggi, terutama terhadap kelompok masyarakat yang rentan (Purnomo dan Suryawati, 2009; Susanto dkk, 2012) terserang COVID-19, yaitu orang-orang yang berusia lanjut, dan mereka yang memiliki masalah medis mendasar seperti penyakit kardiovaskular, diabetes, penyakit pernapasan kronis, dan kanker lebih rentan untuk terpapar penyakit serius (WHO, 2020).

Berkaitan dengan kondisi yang dialami masyarakat di tengah persebaran COVID19, mengetahui tingkat resiliensi masyarakat melalui siklus adaptasi mereka terhadap perubahan yang terjadi selama pandemi menjadi hal yang penting untuk diketahui, karena baik desa yang terdampak, maupun desa yang tidak terdampak seperti Desa Wotsogo, masyarakatnya diharapkan memiliki tingkat resiliensi atau daya lenting yang tinggi dalam menghadapai pandemi COVID-19, terutama dalam menyongsong New Normal Era.

\section{METODE}

Metode yang digunakan dalam penelitian ini adalah metode penelitian deskriptif kualitatif, dengan strategi studi kasus untuk menyelidiki fenomena empiris resiliensi masyarakat Desa Wotsogo dalam menghadapi pandemi COVID-19. Data terkait momen persebaran dan tingkat resiliensi tersebut diperoleh melalui wawancara semi struktur kepada Pemerintah Desa, Ketua RW/RW yang dipilih secara purposive sampling, dan masyarakt Desa Wotsogo yang dipilih secara accidental sampling, serta data hasil pencatatan penduduk/non-penduduk yang masuk ke Desa Wotsogo selama masa pandemi COVID-19. Teknik analisis yang digunakan untuk mengetahui momen persebaran COVID-19 di Desa Wotsogo adalah teknik analisis model interaktif Miles dan Huberman (1986), yang terdiri atas reduksi data untuk menyederhanakan data ke 
dalam 4 tahap siklus adaptif yaitu tahap pertumbuhan, tahap konservasi, tahap pelepasan, dan tahap reorganisasi; penyajian data berupa diagram siklus adaptif dengan konsep Panarchy; dan penarikan kesimpulan untuk mengetahui tahap atau fase siklus adaptif pada tiap-tiap momen persebaran COVID-19 di Desa Wotsogo. Adapun teknik analisis untuk mengetahui tingkat resiliensi masyarakat Desa Wotsogo yaitu menggunakan skoring terhadap faktor-faktor yang berpengaruh terhadap resiliensi berdasarkan tabulasi dari Cutter et al (2010) dengan modifikasi peneliti terkait pandemi COVID-19.yang meliputi faktor kesehatan, fisik, sosial, ekonomi, tata ruang, dan kebijakan.

\section{HASIL DAN PEMBAHASAN}

\section{Momen Persebaran COVID-19 di Desa Wotsogo}

Momen persebaran COVID-19 di Desa Wotsogo bisa dibedakan menjadi tiga, yaitu momen ketika perkembangan awal COVID-19 di Indonesia, momen ketika mulai ada pemberlakuan kebijakan-kebijakan yang berkaitan dengan COVID-19, momen menuju new normal. Dengan mengkombinasikan Teori Siklus Adaptif dengan Panarchy (Gunderson and Holling, 2002), visualisasi ketiga momen tersebut dengan masing-masing tahapannya dapat dilihat pada Gambar 1 berikut ini:

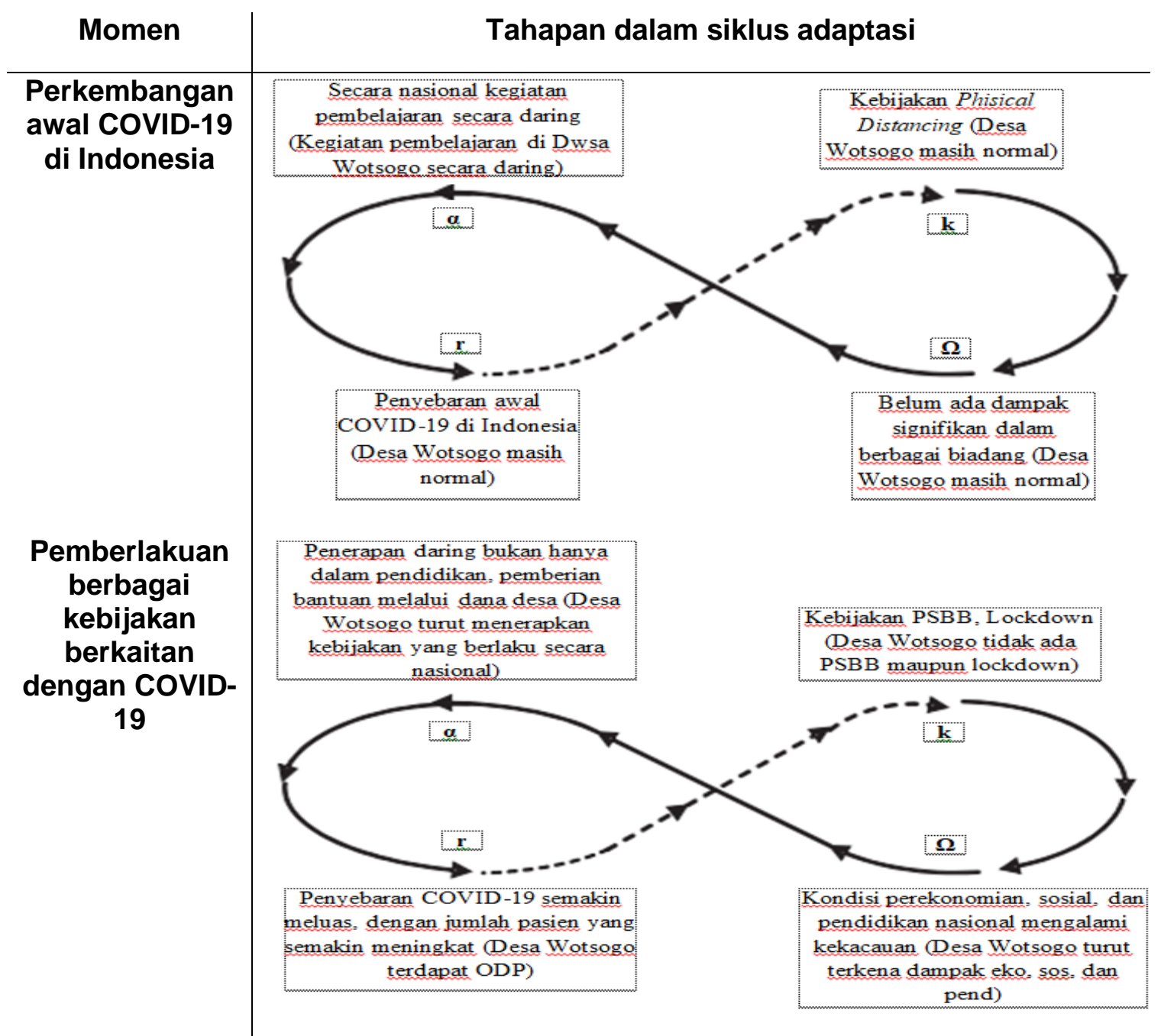




\section{Menuju New Normal}

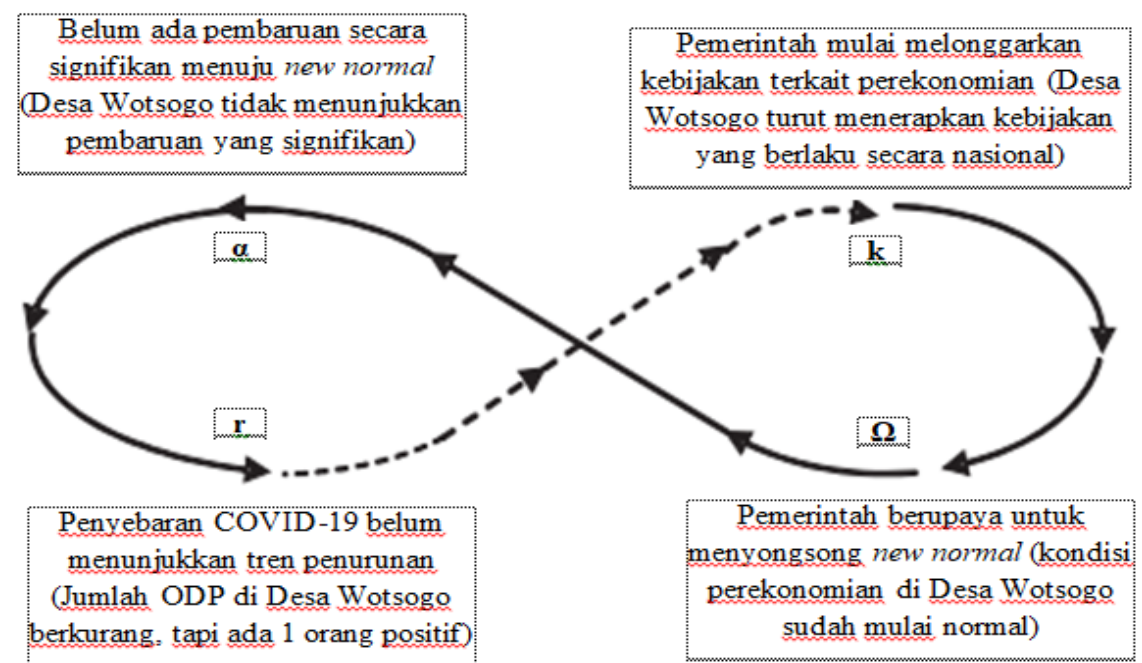

Gambar 1. Visualisasi Momen Persebaran COVID-19 di Desa Wotsogo

Berdasarkan visualisasi momen persebaran COVID-19 di Desa Wotsogo pada Gambar 1, secara lebih rinci keterkaitan antara tahap atau fase siklus adaptif dengan masing-masing momen dapat dilihat pada Tabel 1 di bawah ini.

Tabel 1. Momen Persebaran COVID-19 di Desa Wotsogo

\begin{tabular}{|c|c|c|c|}
\hline \multirow[t]{2}{*}{ Tahap } & \multicolumn{3}{|c|}{ Momen Persebaran } \\
\hline & $\begin{array}{l}\text { Perkembangan awal } \\
\text { COVID-19 di } \\
\text { Indonesia }\end{array}$ & $\begin{array}{c}\text { Pemberlakuan } \\
\text { berbagai } \\
\text { kebijakan } \\
\text { berkaitan dengan } \\
\text { COVID-19 }\end{array}$ & $\begin{array}{c}\text { Menuju New } \\
\text { Normal }\end{array}$ \\
\hline $\begin{array}{l}\text { Pertumbuhan } \\
\text { (r) }\end{array}$ & 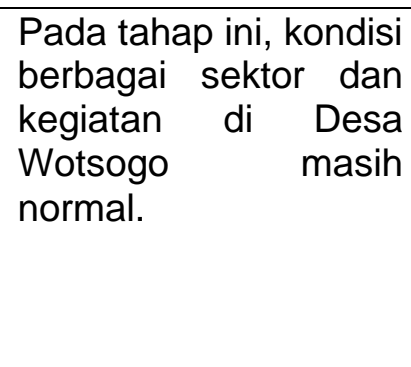 & $\begin{array}{l}\text { Pada tahap ini, } \\
\text { tidak terdapat PDP } \\
\text { di Desa Wotsogo, } \\
\text { tapi ada sekitar } \\
389 \text { orang ODP } \\
\text { yang merupakan } \\
\text { pemudik }\end{array}$ & $\begin{array}{l}\text { Pada tahap ini, } \\
\text { ODP di Desa } \\
\text { Wotsogo } \\
\text { berkurang karena } \\
\text { kembali } \\
\text { perantauan, tetapi } \\
\text { ada } 1 \text { orang yang } \\
\text { positif COVID-19. }\end{array}$ \\
\hline Konservasi (k) & $\begin{array}{l}\text { Pada tahap ini, kondisi } \\
\text { perekonomian, sosial } \\
\text { dan pendidikan di } \\
\text { Desa Wotsogo masih } \\
\text { normal. }\end{array}$ & $\begin{array}{l}\text { Pada tahap ini, di } \\
\text { Desa Wotsogo } \\
\text { tidak ada PSBB } \\
\text { maupun lockdown }\end{array}$ & $\begin{array}{l}\text { Pemerintah mulai } \\
\text { melonggarkan } \\
\text { kebijakan yang } \\
\text { berkaitan dengan } \\
\text { kegiatan } \\
\text { perekonomian } \\
\text { (untuk mengurangi } \\
\text { dampak COVID-19 } \\
\text { dalam bidang } \\
\text { ekonomi), tetapi } \\
\text { dalam bidang } \\
\text { sosial masih }\end{array}$ \\
\hline
\end{tabular}




\begin{tabular}{|c|c|c|c|}
\hline & & & $\begin{array}{l}\text { dilakukan } \\
\text { pembatasan, } \\
\text { dalam bidang } \\
\text { pendidikan pun } \\
\text { kegiatan } \\
\text { pembelajaran } \\
\text { masih dilakukan } \\
\text { secara daring, } \\
\text { termasuk di Desa } \\
\text { Wotsogo, }\end{array}$ \\
\hline $\begin{array}{c}\text { Pengaturan } \\
\text { Ulang }(\Omega)\end{array}$ & $\begin{array}{l}\text { Pada tahap ini, kondisi } \\
\text { kondisi r ekonomi, } \\
\text { sosial, dan pendidikan } \\
\text { di Desa Wotsogo } \\
\text { belum menunjukkan } \\
\text { dampak ryang } \\
\text { signifikan dari COVID- } \\
19 .\end{array}$ & $\begin{array}{l}\text { Pada tahap ini, } \\
\text { kondisi } \\
\text { perekonomian di } \\
\text { Desa Wotsogo } \\
\text { sudah mulai } \\
\text { terganggu, kondisi } \\
\text { sosial sudah } \\
\text { diberlakukan } \\
\text { pembatasan } \\
\text { bahkan peniadaan } \\
\text { kegiatan perkumpulan; } \\
\text { perkum bidang } \\
\text { dalam pendidikan } \\
\text { kegiatan pembelajaran } \\
\text { dilaksanakan } \\
\text { secara daring. }\end{array}$ & $\begin{array}{l}\text { Pada tahap ini, } \\
\text { kondisi } \\
\text { perekonomian di } \\
\text { Desa Wotsogo } \\
\text { sudah } \quad \text { mulai } \\
\text { normal, yang } \\
\text { ditandai } \\
\text { beroperasinya } \\
\text { warung-warung } \\
\text { seperti sedia kala. }\end{array}$ \\
\hline Pembaruan ( $\alpha)$ & $\begin{array}{l}\text { Pada tahap ini, kondisi } \\
\text { ekonomi dan sosial di } \\
\text { Desa Wotsogo masih } \\
\text { normal, tapi dalam } \\
\text { bidang pendidikan, } \\
\text { kegiatan } \\
\text { pembelajaran } \\
\text { dilakukan secara } \\
\text { daring. }\end{array}$ & 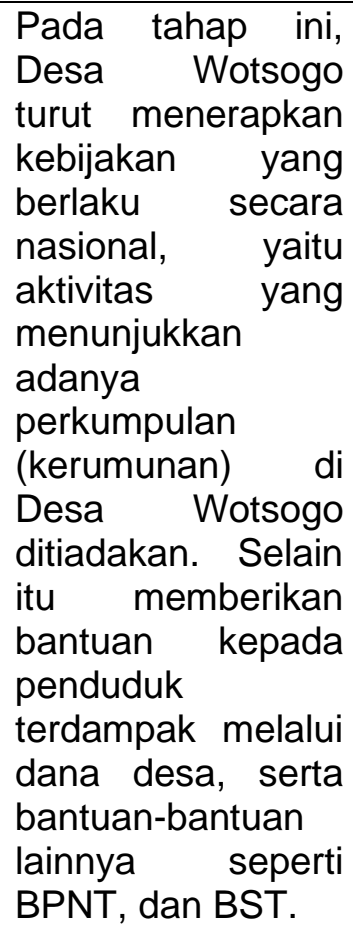 & $\begin{array}{l}\text { Pada tahap ini, } \\
\text { Desa Wotsogo } \\
\text { tidak menunjukkan } \\
\text { pembaruan yang } \\
\text { signifikan, karena } \\
\text { dampak yang } \\
\text { dialami juga tidak } \\
\text { signifikan }\end{array}$ \\
\hline
\end{tabular}

Sumber: Analisis Peneliti 
Berdasarkan ketiga momen tersebut, siklus adaptif dari tahap satu menuju tahap lainnya belum menunjukkan perubahan yang signifikan. Akan tetapi, ketika menuju momen yang kedua yaitu ketika pemerintah telah menerapkan beragam kebijakan, kondisi ekonomi, sosial, dan pendidikan telah mengalami perubahan signifikan karena harus benar-benar menerapkan protokol kesehatan secara ketat, terutama di wilayah terdampak. Pada momen kedua ini terjadi ketidakstabilan dalam berbagai bidang. Sedangkan ketika menginjak pada momen ketiga yaitu momen menuju New Normal, kondisi ekonomi dan sosial sudah mulai mengarah pada kondisi normal atau kestabilan, meskipun dalam pendidikan masih berlaku pembelajaran secara daring.

Dari perubahan antar momen bisa kita cermati bahwa terdapat pengulangan kondisi yaitu dari yang awalnya stabil dan akan berakhir stabil kembali, sebagaimana konsep siklus adaptif yang dikemukakan oleh Holling (1973) bahwa rangkaian momen tersebut dapat secara jelas menggambarkan hubungan satu tahapan kejadian dan tahapan kejadian berikutnya berlangsung dalam siklus-siklus adaptasi berulang. Siklus berulang tersebut juga telah dikaji oleh Purnomo dan Suryawati (2009). Berdasarkan penelitian tersebut diketahui bahwa siklus adaptif berawal dari adanya bencana alam berupa sebuah letusan gunung api pada Tahun 1982 yang membuat masyarakat mempersipakan sebuah respon untuk mempertahankan keberlanjutan mereka secara sosial dan ekonomi, dalam terminologi Holling (2000), periode tersebut dapat dogolongkan ke dalam tahap reorganisasi atau pembaruan.

Hal itu berlaku juga untuk masyarakat Desa Wotsogo yang berupaya mempertahankan keberlanjutan kehidupan secara sosial dan ekonomi dengan mengikuti kebijakan yang ditetapkan oleh pemerintah pusat melalui Pemerintah Desa Wotsogo, terutama hal-hal yang berkaitan dengan protokol kesehatan untuk menghambat persebaran COVID-19. Perbedaan penelitian dengan penelitian yang dilakukan oleh Purnomo dan Suryawati (2009) tersebut bukan hanya perbedaan jenis bencana, tapi juga dari segi resiliensinya. Dalam penelitian ini sisi ekologisnya tidak dapat ditonjolkan secara detail karena memang dampak bencana pandemi COVID-19 lebih mengarah pada kondisi sosial dan ekonomi. Oleh sebab itu, adaptasi yang dilakukan oleh masyarakat Desa Wotsogo lebih mengarah pada upaya perbaikan kondisi sosial-ekonomi.

Penelitian yang berkaitan dengan pola adaptasi masyarakat juga dilakukan oleh Susanto dkk (2012) yang menekankan pola adaptasi masyarakat pesisir secara sosial dan ekologis terhadap bencana rob, melalui penyiapan peta daerah rawan rob, penyediaan POSKO, menyiapkan sistem peringatan dini untuk lokasi rawan rob, melatih penduduk untuk selalu siaga jika terjadi genangan akibat rob dan banjir kiriman, penyediaan tenaga medis untuk pelayan kesehatan, penyediaan infrastruktur penunjang.

Apabila kita cermati pola adaptasinya secara sosial terdapat kesamaan yaitu penyediaan POSKO yang dalam kasus Desa Wotsogo adalah POSKO Pencegahan COVID-19; penyediaan tenaga medis untuk pelayan kesehatan. Perbedaan lain antara penelitian ini dengan dua penelitian yang disebutkan sebelumnya yaitu pembagian periode tahap atau fase adaptifnya. Dua penelitian yang disebutkan menggunakan periode berdasarkan rentang tahun karena kajiannya bersifat temporal jangka panjang, sedangkan dalam penelitian ini pembagian tahap atau fase adaptif dibedakan berdasarkan momen kondisi persebaran COVID-19 yang secara temporal baru berlangsung beberapa bulan. Meskipun demikian melalui penelitian ini bisa kita ketahui bahwa konsep tentang Siklus Adaptif dan Teori Panarchy bukan hanya dapat diterapkan untuk fenomena yang sifatnya jangka panjang, tapi fenomena dengan jangka pendek dan masih berlangsung pun dapat dibedakan berdasarkan momen-momen yang terjadi, meskipun belum bisa 
sepenuhnya menunjukkan siklus berulang secara rinci pada tahap atau fase siklus adaptif karena persebaran COVID-19 masih berlangsung hingga saat ini.

\section{Resiliensi Masyarakat Desa Wotsogo Dalam Menghadapi Pandemi COVID-19}

Berdasarkan faktor kesehatan, faktor kondisi fisik wilayah, faktor sosial, faktor ekonomi, faktor tata ruang wilayah, dan faktor kebijakan Pemerintah Desa dalam upaya pencegahan COVID-19 dapat diketahui resiliensinya. Berdasarkan hasil skoring terhadap keenam indikator tersebut diketahui bahwa bahwa tingkat resiliensi masyarakat Desa Wotsogo bisa dibedakan menjadi dua, yaitu resiliensi sedang dengan total skor 17 poin yang tersebar di RW I, III, dan IX dan resiliensi tinggi dengan total skor 18 dan 19 poin yang tersebar di wilayah lainnya, seperti yang terlihat pada Gambar 2 berikut ini.

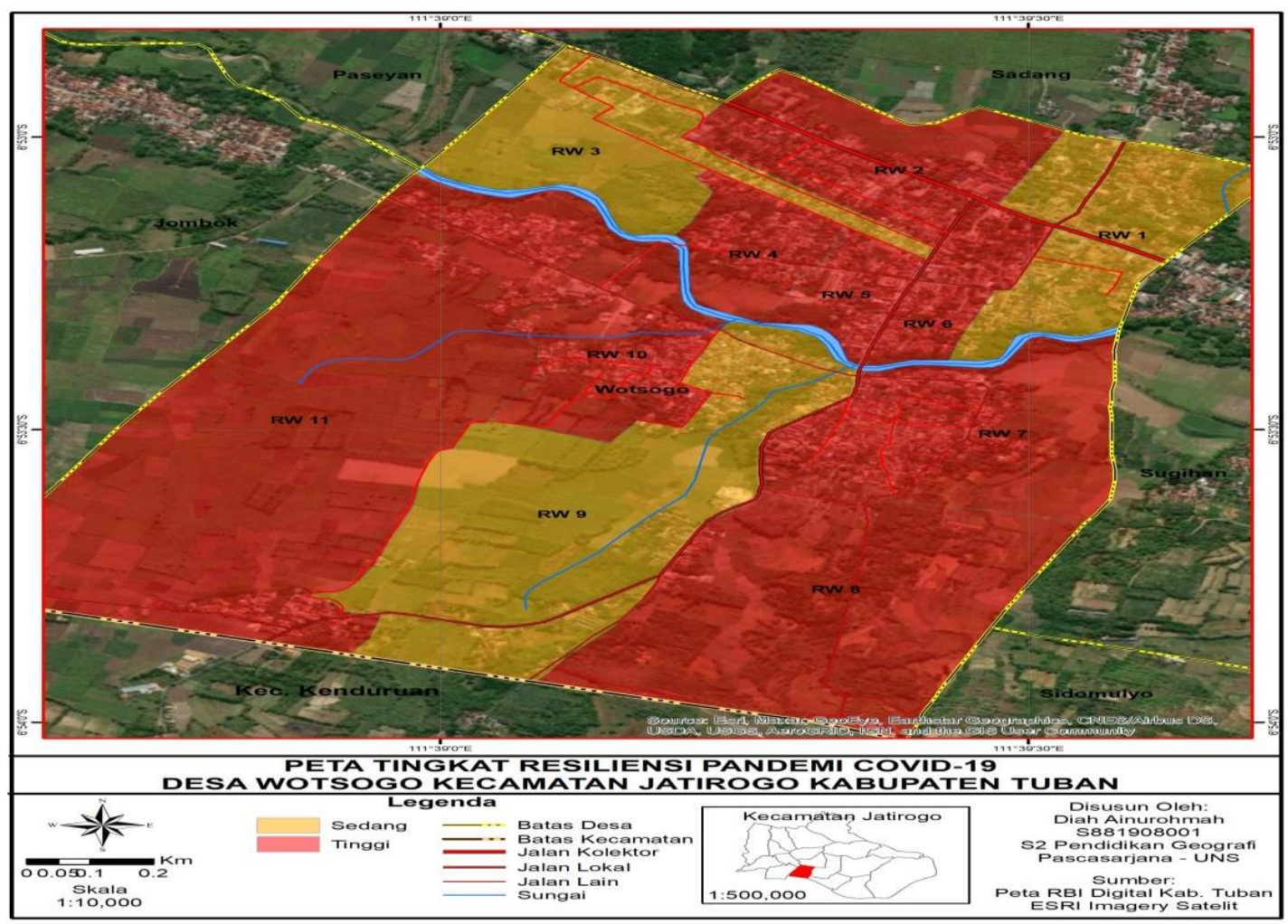

Gambar 2. Peta Tingkat Resiliensi Pandemi COVID-19 Masyarakat Desa Wotsogo

Dari ke-6 faktor yang ada, faktor sosial menjadi faktor paling berpengaruh karena pada dasarnya resiliensi dalam sistem sosial yang ada pada masyarakat akan menambah kapasitas masyarakat tersebut untuk mengantisipasi dan merencanakan masa depan. Tingkat resiliensi sedang dan tinggi sebagaimana yang tertera dalam Gambar 1 tersebut merupakan refleksi derajat kemampuan sebuah sistem kompleks yang adaptif untuk untuk mengorganisasikan diri secara mandiri, serta derajat kemampuan sistem tersebut membangun kapasitas belajar dan beradaptasi terhadap kehidupan sosial di tengah pandemi COVID-19, sehingga harus memperhatikan dan menjalankan dengan seksama protokol kesehatan yang dianjurkan sebagai upaya pencegahan persebaran COVID-19.

Masyarakat Desa Wotsogo tetap perlu meningkatkan resiliensi lebih tinggi lagi dalam berbagai faktor karena itu merupakan tugas penting bagi setiap orang dalam menghadapi tantangan dan kesulitan hidup. Dengan meningkatkan resiliensi, manusia dapat mengembangkan ketrampilan hidup seperti berkomunikasi, 
kemampuan yang realistik dalam membuat rencana hidup dan mampu mengambil langkah yang tepat bagi hidupnya (Rojas, 2015).

\section{SIMPULAN}

1. Momen persebaran COVID-19 di Desa Wotsogo dapat dibedakan menjadi tiga, yaitu:

a. Momen awal perkembangan COVID-19 di Indonesia yang ditandai masih stabilnya kondisi ekonomi dan sosial di Desa Wotsogo, tapi pembelajaran sudah dilakukan secara daring sesuai instruksi pemerintah pusat.

b. Momen pemberlakuan kebijakan berkaitan dengan COVID-19 yang ditandai dengan terganggunya kondisi ekonomi dan sosial masyarakat Desa Wotsogo, sehingga pemerintah pusat menginstruksikan agar masyarakat yang terdampak mendapatkan bantuan dana sosial dan secara sosial mulai digencarkan sosialisasi pencegahan persebaran COVID-19 oleh Satgas Siaga COVID-19 Desa Wotsogo.

c. Momen menuju New Normal yang ditandai oleh kondisi ekonomi dan sosial di Desa Wotsogo yang sudah mulai distabilkan kembali, seperti pemberian izin kepada pemilik warung untuk buka seperti jam normal sebelum ada COVID dan secara sosial sudah tidak ada penutupan jalan.

2. Tingkat resiliensi masyarakat Desa Wotsogo yang ditentukan berdasarkan enam faktor yaitu kesehatan, fisik wilayah, sosial, ekonomi, tata ruang, dan kebijakan, bisa bisa dibedakan menjadi dua, yaitu resiliensi sedang yang meliputi wilayah RW I, III, IX; dan resiliensi tinggi meliputi wilayah RW II, IV, V, VI, VII; VIII, X, dan XI. Dengan mengetahui tingkat resiliensi tersebut, diharapkan dapat menjadi sumber pembelajaran bagi masyarakat tentang pentingnya mengikuti protokol kesehatan untuk memutus rantai persebaran COVID-19.

\section{DAFTAR PUSTAKA}

BPK RI. (2020). Peraturan Pemerintah (PP) tentang Pembatasan Sosial Berskala Besar dalam Rangka Percepatan Penanganan Corona Virus Disease 2019 (COVID-19). Diakses dari https://peraturan.bpk.go.id/.

BPK RI. (2020). Keputusan Presiden (KEPPRES) tentang Penetapan Bencana Nonalam Penyebaran Corona Virus Disease 2019 (COVID-19) Sebagai Bencana Nasional. Diakses dari https://peraturan.bpk.go.id/.

Cutter, S. L., Burton, C. G., \& Emrich, C. T. (2010). Disaster Resilience Indicators for Benchmarking Baseline Conditions. Journal of Homeland Security and Emergency Management, 7(1). https://doi.org/10.2202/1547-7355.1732.

Holling, C. S. (1973). Resilience and Stability of Ecological Systems. Annu.Rev.Ecol.Syst., 4, 1-23. doi:10.1146/annurev.es.04.110173.000245.

Holling, C.S. \& Gunderson, L.H. (2002). Resilience and Adaptive Cycles. In L.H. Gunderson \& C.S. Holling (Eds.). Panarchy: Understanding Transformations in Human and Natural Systems. Washington: IslandPress.

Iswara, A. (2020, April 21). WHO Paparkan Bukti Covid-19 Bukan Berasal dari Lab di Wuhan. Kompas Online. Diakses dari https://www.kompas.com/.

Kementrian Dalam Negeri RI. (2020). Peraturan Menetri Dalam Negeri Republik Indonesia Nomor 20 Tahun 2020 Tentang Percepatan Penanganan COVID-19 Di LIngkungan Pemerintah Daerah. Diakses dari https://www.kemenkeu.go.id/.

Nasution, A. D. (2020, April 27). Ilmuwan di Singapura Prediksi Kasus Corona RI Mulai Berakhir Awal Juni. Katadata Online. Diakses dari https://katadata.co.id/.

Purnomo, A dan Siti H. Suryawati. (2009). Siklus Adaptif, Resiliensi Dan Isu Keberlanjutan Di Segara Anakan. Jurnal Bijak dan Riset Sosek KP. Vol.4 No.2, 2009. 
Rojas, L. F. (2015). Factors Affecting Academic Resilience in Middle School Students: A Case Study. GiST Education and Learning Research Journal, 11(11), 63-78. https://doi.org/10.26817/16925777.286.

Susanto, A dkk. (2012). Analisis Pola Adaptasi Dan Mitigasi Kerentanan Masyarakat Pesisir Terhadap Tekanan Sosio-Ekologis (Studi Kasus Pesisir Kota Semarang, Jawa Tengah). Jurnal Sosialisasi Pendidikan Sosiologi-FIS UNM.

Syambudi, I. (2020, Agustus 23). Update Corona Indonesia 23 Agustus: Jakarta \& Jawa Timur Tertinggi. Tirto Online. Diakses dari https://tirto.id/.

Syafrizal, Z. A dkk. (2020). Pedoman Umum Menghadapi Pandemi COVID-19 Bagi Pemerintah Daerah. Jakarta: Tim Kerja Kementrian Dalam Negeri.

USAID. (2013). Resilience Measurement Practical Guidance Note Series. USA: Mercy Corps.

Utami, C. T. (2017). Self-Efficacy dan Resiliensi: Sebuah Tinjauan Meta-Analisis. Buletin Psikologi, 25(1), 54-65. https://doi.org/10.22146/buletinpsikologi.18419.

World Health Organization. (2020). Coronavirus Overview. Diakses dari https://www.who.int/. 